\title{
OSVRT NA RJEŠENJE USTAVNOG SUDA RH BR: U-I-4175/2013-PP od 27. VIII. 2013.
}

\author{
UDK: 340. $13: 347.7(497.5)$ \\ Primljeno: 1.1. 2018. \\ Stručni rad
}

\begin{abstract}
Predstečajna nagodba koja je propisana Zakonom o financijskom poslovanju i predstečajnoj nagodbi (NN 108/12,144/12,81/13, 112/13) podsjeća na nekadašnju izvanstečajnu prinudnu nagodbu pred sudom. Intencija ovog Zakona bila je propisati pravne norme kojima bi se omogućilo hitro i učinkovito saniranje insolventnih, nelikvidnih i prezaduženih gospodarskih subjekata. U tom Zakonu nema naznake da bi takva nagodba bila prisilnog karaktera, ali se tijekom njegove primjene u praksi uočilo da pojedine njegove odredbe upućuju na takvu mogućnost. Zbog toga je došlo do podnošenja zahtjeva za ocjenu ustavnosti njegovih odredbi Ustavnom sudu RH, koje pojedine sudionike predstečajne nagodbe stavljaju u povoljni položaj te na taj način omogućavaju zloporabe na koje se ukazivalo u podnesenom zahtjevu. Ustavni sud RH u svezi s podnesenim zahtjevom donio je Rješenje pod brojem: U-I-4175/2013-PP od 27. kolovoza 2013. godine kojim je u preliminarnom postupku, uvažavajući djelomično podnesene prigovore dužnika u stečajnoj nagodbi, podneseni zahtjev preoblikovao u prijedlog za ocjenu suglasnosti navedenog Zakona, odnosno pojedinih njegovih odredbi s Ustavom RH, ukinuo je rješenje kojim je bilo određeno zastajanje s postupkom i naložio njegovo bezodložno nastavljanje. Kako je Ustavni sud RH naglasio da je doneseno Rješenje precedentnog karaktera, autor je analizirao zauzeta stajališta Ustavnog suda RH koja su bila temeljem donesenih odluka i došao do spoznaje da je, s obzirom na važnost ove problematike, moglo i trebalo biti doneseno drukčije Rješenje te smatra da isto ne bi trebalo ubuduće imati presedanski karakter.
\end{abstract}

Ključne riječi: Ustavni zakon, zahtjev, prijedlog, zastajanje s postupkom, prethodni prigovori, preliminarni postupak, kvalificirani pokretač

Sloboda je spoznaja nužnog, a to su nužno profesionalne norme i odgovornost prema

istini

(Hegel)

1 Dr. sc. Mladen Pavlović, sudac Suda časti pri HGK Zagreb; e-mail: mladen.pavlovic 39@ gmail. com; Domovinskog rata 43/IV., Split 
Uvod. 1. Činjenice i okolnosti konkretnog slučaja; 2. Preliminarni postupak pred Ustavnim sudom; 3. Tretman prethodnih prigovora sudionika u postupku; 4. Pravna ocjena Ustavnog suda; 4.1. Locus standi u smislu odredbe čl. 37. st. 1. Ustavnog zakona; 4.2. Suglasnost zahtjeva ratione materiae iz čl. 37. st. 1. Ustavnog zakona; 4.3. Ostali propusti podnositelja zahtjeva koji mogu biti predmet prethodnih prigovora; 5. Odlučivanje Ustavnog suda o prijedlogu za pokretanje postupka; 5.1. Što se očekuje od Ustavnog suda po preoblikovanom prijedlogu za ocjenu ustavnosti ZFPPN-a?; 5.2. Ogledni primjer prijedloga za pokretanje postupka pred Ustavnim sudom; 6. Lamentiranje po pojedinim stajalištima Ustavnog suda; 6.1. O institucionalnom pristupu i kvalificiranim pokretačima ustavnosudskog postupka; 6.2. Pretvorba zahtjeva u prijedlog za ispitivanje ustavnosti ZFPPN-a i zastoj postupka; 6.3. O preliminarnom postupku i prethodnim prigovorima; 6.4. O ukidanju rješenja o zastajanju s postupkom i njegovim nastavljanjem; 6.5. O ostalim nedostacima koje sadržava podnesak uređujućeg suca pojedinca; Zaključna razmatranja.

\section{UVOD}

U Narodnim novinama Republike Hrvatske br.108/13 od 30. kolovoza 2013. god. objavljeno je Rješenje Ustavnog suda Republike Hrvatske Broj: U-I4175/2013-PP od 27. kolovoza 2013. god. kojim je u izreci utvrđeno da je u ovom rubriciranom predmetu podnesen prijedlog od strane suca pojedinca Trgovačkog suda u Zagrebu za pokretanje postupka za ocjenu suglasnosti s Ustavom Zakona o financijskom poslovanju i predstečajnoj nagodbi (NN br. 108/12, 144/12-Uredba i 81/13 - u daljnjem tekstu ZFPPN) u smislu odredbe čl. 38. st. 1. Ustavnog zakona o Ustavnom sudu RH (NN br. 99/99, 29/02, 49/02 - pročišćeni tekst), a ne zahtjev za ocjenu ustavnosti pojedinih odredbi citiranog Zakona u smislu odredbe čl. 37. st. 1. Ustavnog zakona, kako je to tražio podnositelj zahtjeva.

Navedenim Rješenjem Ustavnog suda ujedno je ukinuto Rješenje Trgovačkog suda Zagreb br. 66. Stpn 7/13 od 22. srpnja 2013. o zastajanju s postupkom predstečajne nagodbe u predmetu Trgovačkog suda u Zagrebu Stpn 7/13 te je naloženo njegovo bezodložno nastavljanje.

Ustvani sud u obrazloženju svojeg rješenja navodi da je dana 29. srpnja 2013. god. Dalekovod d.d. Zagreb, kao dužnik u predmetu predstečajne nagodbe pod br. Stpn br. 7/13 Trgovačkog suda u Zagrebu, podnio Ustavnom sudu podnesak, koji je, prema shvaćanju Ustavnog suda, nazvao „ustavnom tužbom“, a u kojem je iznio prethodne prigovore protiv Rješenja br. 66 Stpn - 7/13 od 22. srpnja 2013. Trgovačkog suda Zagreb o zastajanju s postupkom. U toj „,ustavnoj tužbi“, odnosno prethodnim prigovorima, u Dalekovodu d.d. Zagreb ističu da sudac pojedinac Trgovačkog suda u Zagrebu nije ovlašten na podnošenje zahtjeva za ocjenu suglasnosti ZFPPN-a s Ustavom, jer da takvu ovlast ima samo Trgovački sud, pa zbog toga nije bio ni ovlašten donijeti rješenje o zastajanju s postupkom predstečajne nagodbe, te da je takvu odluku o pokretanju postupka za ocjenu neustavnosti ZFPPN-a donio proizvoljno i bez navođenja konkretnih pravnih odredbi koje bi bile navodno neustavne, a koje prigovore je Ustavni sud u preliminarnom postupku 
uvažio, dok je ostale odbacio, jer da nemaju svojstvo prethodnih prigovora na podnesak suda predan u predmetu broj: U-I-4175/2013 u smislu odredbe čl. 37. st. 1. Ustavnog zakona o Ustavnom sudu RH (NN 99/99, 29/02 i 49/02 - pročišćeni tekst - u daljnjem tekstu osvrta Ustavni zakon).

Premda Ustavni sud naglašava da njegova prethodna utvrđenja, koja ćemo u nastavku razmotriti, ukazuju na bespredmetnost nastavka postupka po zahtjevu podnositelja u rubriciranom predmetu, ta utvrđenja i doneseno Rješenje, prema navođenju samog Ustavnog suda, presedanskog su karaktera. Zbog toga zaslužuju pobližu opsrevaciju u svezi sa zauzetim stajalištima Ustavnog suda po razmatranim pitanjima podnošenja zahtjeva u smislu čl. 37. st. 1. Zakona o Ustavnom sudu ili pak prijedloga u smislu odredbe čl. 38. st. 1. istog zakona, opravdanog ili neopravdanog razloga za zastajanje s postupkom predstečajne nagodbe, tretiranja prethodnih prigovora Dalekovoda d.d. Zagreb i drugih važnih pitanja na koje ukazuje Ustavni sud, a koja su interesantna, ne samo u konkretnom slučaju, nego i u buduće kada budu povrijeđena ustavna prava koja treba zaštititi.

Tako prof. dr. sc. Branko Smerdel u svojem radu „Ustav RH nakon ustavnih promjena 2010. godine“, objavljenom u Hrvatskoj pravnoj reviji, Zagreb, br. 9/2010. ističe da se razumijevanje posljedica primjene načela vladavine prava iz odredbe čl. 3. Ustava Republike Hrvatske (NN 56/90, 135/97, 8/98 - pročišćeni tekst, 113/00, 124/00 - pročišćeni tekst, 28/01, 41/01 - pročišćeni tekst, 55/01 - ispr. i 76/10 - u daljnjem tekstu Ustav) i s njim u skladu supremacije Ustava kao pravnog akta probija nevjerojatno sporo i s poteškoćama u hrvatskoj politici i pravnoj praksi. U modernoj demokratskoj državi Ustav se primjenjuje neposredno i ni u kojem slučaju ne predstavlja lex imprefecta, već su ga se dužni pridržavati i štititi svi pojedinci i svi sudovi i sva državna tijela, a na prvom mjestu Ustavni sud Republike Hrvatske. U hrvatskoj pravnoj teoriji i praksi tek se u posljednje vrijeme uspostavlja temeljno shvaćanje o primarnoj pravnoj naravi Ustava kao pravnog akta koji se primjenjuje izravno te su se na njega ovlašteni pozivati svi fizički i pravni subjekti. To sigurno zaoštrava pitanje objektivne i stručne kvalitete svih sudskih odluka, a naročito rješenja i odluka Ustavnog suda. Pri tome se ne misli samo na nomotehničku jasnoću teksta, nego i na pitanje realnog utemeljenja ustavnih rješenja, koje omogućavaju prilagodbu putem metode pravne interpretacije koja je prihvatljiva. Potaknuti ovim napisom i citiranim Rješenjem, iznosimo svoje viđenje.

Zato ćemo u nastavku razmotriti činjenice i okolnosti konkretnog slučaja, tijek preliminarnog postupka pred Ustavnim sudom, prethodne prigovore sudionika u postupku, pravnu ocjenu Ustavnoga suda i na kraju navesti ogledni primjer prijedloga (zahtjeva) za pokretanje postupka za ocjenu suglasnosti nekog propisa s Ustavom te našim lamentiranjem glede zauzetih stajališta od strane Ustavnog suda sa zaključnim napomenama. 


\section{1. ČINJENICE I OKOLNOSTI KONKRETNOG SLUČAJA}

Dalekovod d.d. Zagreb podnio je Financijskoj agenciji, Regionalnom centru Zagreb, dana 14. studenoga 2012. god. prijedlog za otvaranje predstečajne nagodbe. Nagodbeno vijeće HR 01 je rješenjem klasa: UP-I-/110/07/12-01/83, Ur. broj: 04-06-12-83-23 od 20. prosinca 2012. god. pod toč. I. izreke otvorilo postupak predstečajne nagodbe nad Dalekovodom d.d. Zagreb kao dužnikom. Nakon provedenih ročišta za utvrđivanje tražbina i za glasovanje o Planu financijskog restrukturiranja nagodbeno je vijeće 9. travnja 2013. god. donijelo rješenje kojim se utvrđuje da su za navedeni Plan glasovali vjerovnici čije tražbine čine potrebnu većinu i da je postupak proveden u skladu s odredbama Zakona o financijskom poslovanju i predstečajnoj nagodbi.

Prijedlog za sklapanje predstečajne nagodbe Dalekovod d.d. Zagreb podnio je Trgovačkom sudu u Zagrebu dana 26. travnja 2013. god., a podneskom od 7. svibnja 2013. god. obavijestio je Trgovački sud u Zagrebu da su protiv rješenja nagodbenog vijeća Financijske agencije od 9. travnja 2013. god. podnesene žalbe uslijed čega je predložio da taj sud prekine postupak do nastupa izvršnosti rješenja nagodbenog vijeća. Podneskom od 31. svibnja 2013. god. Dalekovod d.d. Zagreb obavijestio je Trgovački sud da su u međuvremenu žalbe vjerovnika odbijene te da je navedeno rješenje nagodbenog vijeća steklo potvrdu izvršnosti dana 31. svibnja 2013. god. zbog čega predlaže nastavak postupka predstečajne nagodbe pred Trgovačkim sudom u Zagrebu.

Nakon toga, uređujući sudac pojedinac određuje ročište radi sklapanja predstečajne nagodbe za 23. srpnja 2013. god. rješenjem od 12. srpnja 2013. god. pod br. Stpn 7/13. Tim je rješenjem odredio da će se postojanje pretpostavki za sklapanje predstečajne nagodbe utvrditi najkasnije do zakazanog ročišta 23. srpnja 2013. god. Paralelno s tim rješenjem od 16. srpnja 2013. god. uređujući sudac pojedinac Trgovačkog suda u Zagrebu naložio je Dalekovodu d.d. Zagreb da ispravi prijedlog sadržaja predstečajne nagodbe, tako da pobliže naznači i objasni različite kategorije vjerovnika te navede sadržaj čl. 212. i 213. nagodbe. Također mu je naloženo da se decidirano očituje o činjenici, što je prijedlogom nagodbe predviđeno, da se samo pojedini vjerovnici namiruju iz prodaje poslovnih udjela u društvu Dalekovod Professio d.o.o., nakon čega je Dalekovod d.d. Zagreb u tom smislu dostavio određene podneske Trgovačkom sudu.

Međutim, 22. srpnja 2013. god. uređujući sudac Trgovačkog suda u Zagrebu donosi rješenje kojim je određeno zastajanje s postupanjem u ovom sudskom postupku predstečajne nagodbe nad Dalekovodom d.d. Zagreb, s time da će se u roku od 8 dana podnijeti Ustavnom sudu Republike Hrvatske zahtjev za ocjenu ustavnosti pojedinih odredbi ZFPPN-a (NN 108/12,144/12 i 81/13). Iz obrazloženja tog rješenja proizlazi da je, tijekom postupanja u ovom sudskom postupku, uređujući sudac utvrdio da pojedine odredbe ZFPPN-a nisu suglasne s Ustavom Republike Hrvatske. Tako je odredbom čl. 37. st. 1. Ustavnog zakona o Ustavnom sudu RH (NN 99/99, 29/02 i 49/02) određeno da, ako sud u postupku koji vodi, 
utvrdi kako zakon koji bi trebalo primijeniti, odnosno pojedina njegova odredba nisu suglasni s Ustavom, zastat ce s postupkom i podnijeti Ustavnom sudu zahtjev za ocjenu suglasnosti zakona, odnosno pojedine njegove odredbe s Ustavom. Ovlast za donošenje odluke o zastajanju s postupkom proizlazi direktno iz odredbe čl. 120. Ustava RH (NN 56/90, 135/97, 8/98, 113/00, 124/00, 28701, 41/01, 55/01, 76/10,85/10 - pročišćeni tekst), kojom je određeno da se sudačka dužnost povjerava osobno sucima. Pored toga, da je odredbom čl. 3. Zakona o sudovima (NN 28/13) propisano da sudovi štite Ustavom, međunarodnim ugovorima i zakonima utvrđeni pravni poredak Republike Hrvatske te osiguravaju jedinstvenu primjenu prava, ravnopravnost i jednakost svih pred zakonom. Razlozi utvrđenja nesuglasnosti pojedinih odredbi ZFPPN-a s Ustavom RH biti će navedeni u Zahtjevu za ocjenu suglasnosti pojedinih odredbi s Ustavom RH. Osim što cee se uputiti Ustavnom sudu RH, razlozi će se unijeti u spis predmeta Stpn 7/13. Protiv donesenog rješenja nije dopušteno izjaviti pravni lijek pozivom na odredbu čl. 278. st. 2. Zakona o parničnom postupku.

Trgovački sud u Zagrebu donosi i drugo rješenje u istoj pravnoj stvari pod istim brojem kao i prethodno rješenje koje se odnosi na odgodu ročišta, kojim je ročište za 23. srpnja 2013. god. odgođeno na neodređeno vrijeme. Međutim, Ustavni sud navodi kako je u ovom preliminarnom postupku relevantno samo citirano rješenje o zastajanju s postupkom predstečajne nagodbe.

Opisana postupanja Trgovačkog suda u Zagrebu izazvala su mnoge polemike i rasprave, koje su još uvijek aktualne, a posebno kada je uređujući sudac, u nastavku postupka koji je slijedio nakon naloga Ustavnog suda za njegovim bezodložnim nastavljanjem, donio Rješenje 66. Stpn - 7/13 od 16. rujna 2013. god. kojim je odbio prijedlog Dalekovoda d.d. Zagreb za sklapanje predstečajne nagodbe od 26. travnja 2013. god., ispravljen 19. srpnja 2013. god., smatrajući da je isti nedopušten i naložio Financijskoj agenciji Zagreb da odmah po zaprimanju ovog rješenja isto objavi na svojim web-stranicama.

\section{PRELIMINARNI POSTUPAK PRED USTAVNIM SUDOM}

Ustavni sud dalje ističe da je Mislav Kolakušić, sudac Trgovačkog suda u Zagrebu, dana 29. srpnja 2013. god. osobno podnio Ustavnom sudu RH zahtjev podredno prijedlog za ocjenu ustavnosti pojedinih odredbi Zakona o financijskom poslovanju i predstečajnoj nagodbi. Dakle, Ustavni sud smatra da je podnositelj zahtjeva, odnosno prijedloga, sudac pojedinac u predmetu Trgovačkog suda u Zagrebu br. Stpn 7/13 (u daljnjem tekstu - uređujući sudac pojedinac). Podnesak koji je uputio Ustavnom sudu RH za ocjenu suglasnosti s Ustavom pojedinih odredbi ZFPPN-a utemeljio je na čl. 37. st. 1. (podredno čl. 38. st. 1.) Ustavnog zakona o Ustavnom sudu RH (u daljnjem tekstu Ustavni zakon o Ustavnom sudu RH ili Ustavni zakon). Podnesak je potpisao uređujući sudac pojedinac, a ovjeren je pečatom Trgovačkog suda u Zagrebu. 
Dana 29. srpnja 2013. god. Dalekovod d.d. Zagreb podnio je Ustavnom sudu podnesak nazvan „ustavna tužba“, u kojem iznosi prigovore protiv rješenja Trgovačkog suda u Zagrebu br. 66 Stpn - 7/13 od 22. srpnja 2013. god. o zastajanju s postupkom predstečajne nagodbe nad njim.

Ustavni sud utvrđuje da protiv rješenja o zastajanju s postupkom na temelju odredbe čl. 37. st. 1. Ustavnog zakona ustavna tužba nije dopuštena, jer nisu ispunjene pretpostavke propisane čl. 62. st. 1. Ustavnog zakona za njezino podnošenje. Međutim, uvažava činjenicu da je Ustavni zakon prepustio ustavnosudskoj praksi pobližu razradu odredbe čl. 37. st. 1. Ustavnog zakona u svjetlu zahtjeva koje postavlja vladavina prava, najviša vrednota ustavnog poretka Republike Hrvatske. Ističe i činjenicu da su sudovi od 1991. god. do danas rijetko podnosili zahtjeve Ustavnom sudu za ocjenu ustavnosti zakona na temelju čl. 37. st. 1. Ustavnog zakona, odnosno čl. 14. st. 1. ranijeg Ustavnog zakona o Ustavnom sudu RH (NN 13/91), a kada su ih i podnosili, Ustavnom sudu nisu dostavljali posebna rješenja o zastajanju s postupkom. U dosadašnjoj praksi Ustavnog suda nije zabilježeno ni osporavanje takvih rješenja pred Ustavnim sudom, pa ne postoji ni izgrađena praksa Ustavnog suda po tom pitanju.

\section{TRETMAN PRETHODNIH PRIGOVORA SUDIONIKA U POSTUPKU}

Zbog toga, pri razmatranju smjera razvitka ustavnosudske prakse vezane uz tu novu pravnu situaciju, Ustavni sud polazi od izravne i neposredne povezanosti pojedinačnog akta o zastajanju sa sudskim postupkom s pitanjima ustavnosti zakona. Zauzeo je stajalište o načelnoj odgovarajućoj primjenjivosti pravila koje je Europski sud za ljudska prava u Strasbourgu (dalje: ESLJP), primjenjujući Konvenciju za zaštitu ljudskih prava i temeljnih sloboda (NN 18/97, 6/99, 8/99 - pročišćeni tekst, 14/02, 1706 - dalje Konvencija), izgradio u svojoj praksi u svezi s prethodim prigovorima (preliminary objection). Ti prethodni prigovori prvenstveno se tiču dopuštenosti zahtjeva, uključujući suglasnost zahtjeva s Konvencijom i principima na koje ista ukazuje kao što su: ratione materiae, personae, temporis i loci, pitanja vezana uz nadležnost ESLJP-a za odlučivanje o njima i drugih formalnopravnih pitanja (dalje: formalnopravna pitanja).

Odgovarajuća primjena navedenih pravila na pravnu situaciju uređenu odredbom čl. 37. st. 1. Ustavnog zakona znači: U slučaju da je u konkretnom sudskom postupku doneseno rješenje o zastajanju s postupkom na temelju čl. 37. st. 1. Ustavnog zakona u povodu podneska suda kojim se od Ustavnog suda traži ocjena ustavnosti zakona (također pozivom na čl. 37. st. 1. Ustavnog zakona), u domaćem pravnom poretku dopušteni su prethodni prigovori formalnopravne naravi. Ovlaštenje za njihovo podnošenje imaju stranke u sudskom postupku s kojim se zastalo sve dok zastajanje s postupkom traje. Te prethodne prigovore Ustavni sud razmatra u preliminarnom postupku vezanom uz podnesak suda kojim se traži ocjena ustavnosti zakona koji 
se trebao primijeniti u sudskom postupku s kojim se zastalo. Taj se preliminarni postupak vodi pod brojem glavnog predmeta uz dodatak podoznake „PP“.

Primjenjujući navedena pravila na konkretan slučaj, Ustavni sud je utvrdio da se podnesak Dalekovoda d.d. Zagreb, nazvan ,ustavna tužba“, u određenim svojim dijelovima može smatrati prethodnim prigovorima na navedeni podnesak suda u predmetu broj U-I-4175/2013 u smislu čl. 37. st. 1. Ustavnog zakona. Zbog toga se ti dijelovi podneska Dalekovoda d.d. Zagreb razmatraju u ovom preliminarnom ustavnosudskom postupku u izloženom smislu, dok ostali prigovori Dalekovoda d.d. Zagreb nemaju svojstvo prethodnih prigovora na podnesak suda u predmetu U-I-4175/2013 u smislu odredbe dalje čl. 37. st. 1. Ustavnog zakona, pa se odbacuju.

\section{PRAVNA OCJENA USTAVNOG SUDA}

\subsection{Locus standi u smislu odredbe čl. 37. st. 1. Ustavnog zakona}

Ustavni sud dalje navodi kako dosadašnja praksa tog suda pokazuje da se čl. 37. st. 1. Ustavnog zakona ne može tumačiti ni primjenjivati samostalo, nego da to uvijek treba činiti zajedno s čl. 35. alineja 5. i čl. 39. Ustavnog zakona. Pri tome da je relevantan i čl. 36. st. 1. Ustavnog zakona.

Tako odredbama čl. 35. i 36. Ustavnog zakona propisan je krug tijela državne i javne vlasti koja nisu donositelji osporenih akata, a ovlašteni su Ustavnom sudu podnositi zahtjeve kojima se ex lege pokreću ustavnosudski postupci za ocjenu ustavnosti pravnih normi (pri tome je iznimka zakonodavna grana vlasti jer je Hrvatski sabor isključivi donositelj zakona i stoga ne može biti u položaju osporavatelja njihove ustavnosti pa se iz reda zakonodavne vlasti u ulozi osporavatelja pojavljuju njegova radna tijela i tzv. parlamentarna manjina za koju je ocjena ustavnosti zakona kao pravno sredstvo izvorno i stvorena).

Za razliku od osoba određenih u čl. 38. st. 1. Ustavnog zakona, tijela državne i javne vlasti određena odredbama čl. 35. i 36. Ustavnog zakona smatraju se kvalificiranim pokretačima tog ustavnosudskog postupka, a među njima je i Vrhovni sud Republike Hrvatske ili drugi sud, ako pitanje ustavnosti nastane u postupku vođenim pred tim sudovima. Ustavni je sud u svojoj dosadašnjoj praksi smatrao da se Ustavni zakon opredijelio za institucionalni pristup, jer priznaje položaj kvalificiranih pokretača ustavnosudskog postupka za ocjenu ustavnosti pravnih normi samo tijelima državne i javne vlasti kao takvima, uz iznimku koja se tiče već spomenute zakonodavčeve grane vlasti. Zato se, povezujući odredbe čl. 35, alineja 5 s odredbom čl. 39. st. 1. Ustavnog zakona, koji propisuje što svaki zahtjev treba sadržavati, a osobito potpis i pečat podnositelja zahtjeva, kao kvalificirani pokretači postupka ocjene ustavnosti pravnih normi pred Ustavnim sudom mogu pojaviti samo tijela koja zastupaju njihovi čelnici, a ne njihove ustrojstvene jedinice ili fizičke osobe u svojstvu odgovarajućih funkcija unutar tih tijela (kao npr. 
ministri u Vladi RH). Zbog toga Ustavni sud i dalje ustraje na takvom pravnom stajalištu kada je riječ o predsjedniku republike, Vladi Republike Hrvatske, pučkom pravobranitelju i predstavničkim tijelima jedinica lokalne i područne (regionalne) samouprave.

Što se tiče sudbene vlasti, Ustavni sud u dosadašnjoj praksi nije pravio razliku između sudova i ostalih kvalificiranih pokretača postupka ocjene ustavnosti pravnih normi. Ustavni sud nije nikada isključio mogućnost da zahtjev potpiše konkretni sudac ili predsjednik konkretnog vijeća, ali je smatrao da aktivitet suda, kada se obraća Ustavnom sudu u postupku ocjene ustavnosti pravnih normi, jest aktivitet tijela državne vlasti koje pred Ustavnim sudom mora predstavljati predsjednik suda kao najviše tijelo sudske uprave u sudu, a sam zajtjev mora sadržavati i njegov potpis i pečat suda (to je pečat koji pored propisanog sadržaja ima i oznaku: predsjednik suda - op. autora). Iz dosadašnje prakse Ustavnoga suda razvidno je da on nije smatrao kako je Ustavni zakon koji je danas na snazi unio bitne novine u taj institut, osim što je krug kvalificiranih pokretača postupka ocjene ustavnosti pravnih normi proširio pored Vrhovnog suda i na sve druge sudove. Stoga je i dalje ostao na stajalištu da Ustavni zakon nije izjednačio suca s tijelima državne i javne vlasti kao kvalificiranim pokretačima tog postupka. Naime, riječ je o eskludiranju suca kao osobnog nositelja sudačke funkcije u sudovima u smislu čl. 118. st. 1. Ustava samo iz kategorije kvalificiranih pokretača postupka za ocjenu ustavnosti pravne norme pred Ustavnim sudom. Međutim, time nije nikada dovedena u pitanje ovlast suca da osporava ustavnost zakona i drugih propisa pred Ustavnim sudom na temelju odredbe čl. 38. st. 1. Ustavnog zakona, niti njegova ovlast da u konkretnom sudskom postupku odlučuje o svim pitanjima koja su inherentna funkciji suđenja.

Zato je Ustavni sud RH u slučajevima u kojima nisu bile ispunjene pretpostavke propisane odredbama čl. 37. Ustavnog zakona zauzeo stajalište da te podneske neće odbacivati, nego će ih smatrati prijedlogom za pokretanje postupka u smislu odredbe čl. 38. st. 1. Ustavnog zakona. Tako je u slučajevima kada se nije moglo smatrati da zahtjev podnosi sud, uobičajena formulacija u odlukama i rješenjima Ustavnog suda glasila: npr. sudac Općinskog suda u Krku M. R. (u daljnjem tekstu predlagatelj) podnio je prijedlog za ocjenu suglasnosti s Ustavom i zakonom... Ovakva dugogodišnja, ustaljena i jednoobrazna ustavnosudska praksa ima se smatrati ,pravom“ (law) u smislu u kojem relevantnost sudske prakse tumači ESLJP.

Navedena utvrđenja su važna, jer razlikovanje ,zahtjeva“ i „,prijedloga“ može imati konkretne pravne posljedice na prava stranaka u sudskim postupcima. Zato samo kada je rječ o zahtjevu iz čl. 37. st. 1. u svezi s čl. 35. alineja 5 i 39. Ustavnog zakona nadležni sud ima pravnu osnovu za zastajanje s konkretnim sudskim postupkom.

Zbog malog broja podnesenih zahtjeva i zbog nepostojanja konkretnih sudskih odluka o zastajanju s postupkom na temelju odredbe čl. 37. st. 1. Ustavnog zakona do sada nije postojala potreba takvu dugogodišnju ustaljenu i jednoobraznu ustavnosudsku praksu preispitivati kada je riječ o sudovima iz čl. 35. alineja 5. Ustavnog zakona. Ustavni sud u tom smislu prihvaća ustaljeno stajalište ESLJP-a, 
izraženo u predmetu Micallef protiv Malte (presuda, veliko vijeće od 15. X. 2009., zahtjev br.17056/06, par. 81), da ,zbog interesa pravne sigurnosti predvidljivosti i jednakosti pred zakonom Sud ne bi smio odstupiti bez dobrog razloga od svoje prakse koja je stvorena u prijašnjim slučajevima“, ali i stajališta da bi „,propust Suda da održava dinamičan i evolutivan pristup mogao dovesti do kočenja reforme ili napretka". Kako u razmatranom predmetu u ovom ustavnosudskom postupku ne postoji rizik da bi dosadašnja praksa Ustavnog suda bila kočnicom ,reformi ili napretka", u ovom predmetu prednost se mora dati interesima pravne izvjesnosti, predvidljivosti i jednakosti pred zakonom i u tom smislu poštovati dosadašnju ustvanosudsku praksu, koja se i dalje ima smatrati „,pravom“ (law) koje obvezuje i sami Ustavni sud.

Stoga se podnesak što ga je predao uređujući sudac Trgovačkog suda Zagreb osobno Ustavnom sudu dana 29. srpnja 2013. god. ne može smatrati zahtjevom u smislu odredbe čl. 37. st. 1. Ustavnog zakona, jer odstupa od zahtjeva koji proizlazi iz institucionalnog pristupa ovlaštenika, pa se isti ima smatrati prijedlogom za pokretanje postupka za ocjenu suglasnosti s Ustavom ZFPPN-a u smislu odredbe čl. 38. st. 1. Ustavnog zakona. Zbog toga se u postupku predstečajne nagodbe koji se vodi pred Trgovačkim sudom u Zagrebu pod brojem Stpn-7/13 nije smjelo zastati s postupkom.

\subsection{Suglasnost zahtjeva ratione materiae s čl. 37. st. 1. Ustavnog zakona}

Ustavni sud naglašava kako dosadašnja ustavnosudska praksa pokazuje da u predmetima u kojima je bilo utvrđeno da je zahtjev u smislu čl. 37. Ustavnog zakona podnio sud, ali se taj zahtjev odnosio na odredbe zakona ili drugog propisa koje nisu bile primijenjene u postupku vođenim pred tim sudom, takav se zahtjev ima smatrati prijedlogom u smislu odredbe čl. 38. st. 1. Ustavnog zakona.

Ustavni zakon nalaže da pitanje ustavnosti propisa mora nastati u postupku vođenim pred tim sudom. To pak znači da se u zahtjevu mora naznačiti u svezi s kojim se konkretnim postupkom koji se vodi pred sudom pojavilo pitanje ustavnosti određenog zakona, odnosno pojedine njegove odredbe s Ustavom. Dakle, zahtjevom je dopušteno osporavati ustavnost samo onih odredbi zakona koje treba primijeniti u tom sudskom postupku, a ne bilo koje odredbe bilo kojeg zakona. To jasno proizlazi iz odredbe čl. 37. st. 1. Ustavnog zakona. Konačno, tvrdnje o neustavnosti zakonskih odredbi potrebno je obrazložiti na konkretnom predmetu na koje bi se one trebale primijeniti, jer je u primjeni odredbe čl. 37. st. 1. Ustavnog zakona riječ o specifičnoj konkretnoj kontroli ustavnosti pravnih normi.

Uređujući sudac pojedinac u svojem već citiranom podnesku što ga je podnio Ustavnom sudu ne poštuje navedena pravila o sadržaju zahtjeva iz čl. 39. Ustavnog zakona kada je osporio suglasnost s Ustavom pojedinih odredbi ZFPPN-a, jer ih ni na koji način nije povezao s činjenicama i okolnostima konkretnog predmeta koji se vodi pred Trgovačkim sudom u Zagrebu pod brojem Stpn-7/13 u kojem je zastao s 
postupkom, niti je obrazložio razloge zbog kojih smatra da u tom predmetu odredbe ZFPPN-a proizvode učinke koji su protivni Ustavu.

\subsection{Ostali propusti podnositelja zahtjeva koji mogu biti predmet prethodnih prigovora}

Zbog presedanskog karaktera donesenog rješenja Ustavni sud smatra potrebnim i svrsishodnim upozoriti i na druge propuste u primjeni čl. 37. st. 1. Ustavnog zakona koji su počinjeni u ovom postupku, a koji mogu biti također predmetom preliminarnog ispitivanja.

Tako ustavni sud primjećuje da je uređujući sudac pojedinac prvo donio rješenje 22. srpnja 2013. god. o zastajanju s postupkom, a svoj je podnesak Ustavnom sudu podnio tek 29. srpnja 2013. god. Međutim, zahtjevi vladavine prava, a osobito pravne sigurnosti i izvjesnosti, nalažu da zahtjev Ustavnom sudu za ocjenu ustavnosti pravnih normi već postoji u spisu predmeta Trgovačkog suda u Zagrebu u vrijeme donošenja spornog rješenja o zastajanju s postupkom na temelju čl. 37. st. 1. Ustavnog zakona, odnosno da je dostupan strankama (najkasnije) istodobno kad i rješenje o zastajanju s postupkom. Konačno, i sam uređujući sudac pojedinac svoj podnesak podredno naziva prijedlogom za pokretanje postupka za ocjenu suglasnosti s Ustavom ZFPPN-a u smislu čl. 38. st. 1. Ustavnog zakona. Ipak, protivno sadržaju vlastitog podneska i unatoč dugogodišnjoj ustaljenoj i jedoobraznoj ustavnosudskoj praksi, uređujući sudac pojedinac donio je rješenje o zastajanju s postupkom u predmetu Stpn-7/13 Trgovačkog suda u Zagrebu.

Sukladno donesenom rješenju u predmetu broj: U-I-4175/2013, Ustavni sud će u daljnjem tijeku postupka odlučivati o osnovanosti prijedloga za pokretanje postupka za ocjenu suglasnosti ZFPPN-a s Ustavom u smislu čl. 38. st. 1. Ustavnog zakona.

\section{ODLUČIVANJE USTAVNOG SUDA O PRIJEDLOGU ZA POKRETANJE POSTUPKA}

\section{1.Što se očekuje od Ustavnog suda po preoblikovanom prijedlogu za ocjenu ustavnosti ZFPPN-a?}

To što je Ustavni sud u rješenju U-I-4175/2013-PP od 28. kolovoza 2013. utvrdio da je u predmetu U-I-4175/2013 podnesen prijedlog za pokretanje postupka za ocjenu suglasnosti s Ustavom Zakona o financijskom poslovanju i predstečajnoj nagodbi i da će odlučivati o njegovoj osnovanosti za pokretanje postupka po čl. 38 . st. 1. Ustavnog zakona ne znači da će taj prijedlog biti prihvaćen.

Ako pođemo od pretpostavki da po čl. 40. st. 1. Ustavnog zakona prijedlog za pokretanje postupka za ocjenu suglasnosti zakona s Ustavom i suglasnosti 
drugih propisa s Ustavom i zakonom treba sadržavati sve ono što sadrži i zahtjev, a očito je iz prednjih stajališta Ustavnoga suda da je zahtjev, koji se sada smatra prijedlogom, manjkav, odnosno da ne sadrži sve ono što je potrebno da bi se po njemu moglo postupiti, postavlja se pitanje hoće li Ustavni sud u daljnjem tijeku postupku vratiti podnositelju podnesak radi ispravka odnosno dopune prijedloga ili će ga odbaciti, jer ne postoje pretpostavke za odlučivanje o biti stvari. Tako primjerice, zahtjev, prijedlog i ustavnu tužbu koja ne sadrži konkretne i obrazložene razloge možebitne povrede određenog ustavnog prava Ustavni sud će odbaciti, jer ne postoje pretpostavke za odlučivanje o biti stvari.

\subsection{Ogledni primjer prijedloga za pokretanje postupka pred Ustavnim sudom}

Svaka fizička i pravna osoba ima pravo predložiti pokretanje postupka za ocjenu suglasnosti zakona s Ustavom i ocjenu suglasnosti drugih propisa s Ustavom i zakonom te se prezentira prva varijanta:

Prijedlog nasloviti: USTAVNI SUD REPUBLIKE HRVATSKE pb ZAGREB, Varšavska 3

Podnositelj: Ime i prezime, adresa prebivalište ili boravište i OIB za fizičke osobe, a za pravne osobe naziv i sjedište, kako su upisani u određeni registar i OIB te ime i prezime zakonskog zastupnika.

Pozivom na odredbe čl. 38. st. 1, 39. čl. 40. st. 1. i 2. u svezi s čl. 17. st. 1 i čl. 19. st. 1. Ustavnog zakona o Ustavnom sudu RH (NN 49/2002 - pročišćeni tekst) podnosim

$$
\text { prijedlog }
$$

za pokretanje postupka za ocjenu suglasnosti s Ustavom Zakona o posebnom porezu na plaće, mirovine i druge primitke (NN94/09) u cijelosti, te posebno odredaba čl. 1. st. 1., 4., 5., i to s odredbama čl. 1. st. 1., 5., 14., 35., 51., 55. st. 1. Ustava Republike Hrvatske

I. Podnositelj prijedloga ističe da su za ocjenu suglasnosti Zakona o posebnom porezu na plaće, mirovine i druge primitke (NN94/09) s Ustavom RH mjerodavne sljedeće odredbe Ustava RH: 
Čl. 1. st. 1., koji glasi: „Republika Hrvatska je jedinstvena i nedjeljiva demokratska i socijalna država“.

Čl. 5. glasi: „U Republici Hrvatskoj zakoni moraju biti u suglasnosti s Ustavom, a ostali propisi s Ustavom i zakonom. Svatko je dužan držati se Ustava i zakona i poštivati pravni poredak $\mathrm{RH}^{\text {“. }}$

Čl. 14. glasi: „Svatko u Republici Hrvatskoj ima prava i slobode neovisno o njegovoj rasi, boji kože, spolu, jeziku, vjeri, političkom ili drugom uvjerenju, nacionalnom ili socijalnom podrijetlu, imovini, rođenju, naobrazbi, društvenom položaju ili drugim osobinama. Svi su pred zakonom jednaki.

Čl. 35. glasi: „Svakom se jamči štovanje i pravna zaštita njegovog osobnog i obiteljskog života, dostojanstva, ugleda i časti“".

Čl. 51. glasi: „Svatko je dužan sudjelovati u podmirenju javnih troškova u skladu sa svojim gospodarskim mogućnostima. Porezni sustav temelji se na načelima jednakosti i pravednosti“".

Čl. 55. st. 1. glasi: „Svaki zaposleni ima pravo na zaradu kojom može osigurati sebi i obitelji slobodan i dostojan život".

II. Podnositelj prijedloga ukazuje da je odredbom čl. 1. Zakona o posebnom porezu na plaće, mirovine i druge primitke određeno: „Ovim Zakonom u uvjetima gospodarske krize u RH određuje se poseban porez na plaće, mirovine i druge primitke za razdoblje od dana stupanja na snagu ovoga zakona do 31. prosinca 2010. na načelima pravednosti, jednakosti i razmjernosti na temelju kojih je svatko dužan sudjelovati u podmirenju javnih troškova razmjerno svojim mogućnostima“"

Zakonodavac u navedenom članku ističe da se u donošenju spornog zakona vodio trenutnom gospodarskom krizom, načelom pravednosti, jednakosti i razmjernosti na temelju čega su svi građani dužni razmjerno sudjelovati u svladavanju gospodarske krize.

Međutim, upravo protivno utvrđenju iz čl. 1. spornog Zakona, podnositelj prijedloga ističe da se zakonodavac nije vodio načelima pravednosti, jednakosti i razmjernosti, niti je predmetni Zakon usklađen s jednim od temeljnih određenja Republike Hrvatske kao socijalne države.

Podnositelj prijedloga naglašava da je zakonodavac trebao, uzimajući u obzir cjelokupnu socijalnu situaciju, provesti javnu društvenu raspravu prije donošenja ovog Zakona, jer se tim Zakonom građanima RH koji se nalaze u teškoj gospodarskoj situaciji, novim nametima određenim spornim odredbama tog Zakona dodatno pogoršava ionako loša ekonomska situacija.

Odredbom čl. 1. st. 1. Ustava RH određeno je da je Republika Hrvatska jedinstvena i nedjeljiva demokratska i socijalna država, koja se kao socijalna država 
mora brinuti o ekonomskim i drugim socijalnim problemima vlastitih državljana. Navedenom odredbom čl. 1. st. 1. spornog Zakona, kao i spornim Zakonom u cjelini, zakonodavac nije uzeo u obzir Ustavom određenu obvezu RH da bude socijalna država i kao takva u sadašnjem, posebno osjetljivom gospodarskom razdoblju, kada se većina građana nalazi u znatnim zaduženjima, kad se potrošnja građana sve više smanjuje, kada većina građana ne uspijeva podmirivati niti svoje tekuće obveze nužne za goli život - ne smije donositi zakone kojima će se ti isti građani dovesti u još teži ekonomski i socijalni položaj.

Zakonodavac je odredbom čl. 4. Zakona o posebnom porezu na plaće, mirovine i druge primitke (NN94/09) odredio: „Poseban porez na plaće, mirovine i druge primitke rezidenata plaća se na:

primitke od nesamostalnog rada (plaću i mirovinu) prema zakonu o porezu na dohodak,

primitke od kojih se utvrđuje drugi dohodak prema zakonu o porezu na dohodak,

mirovine na koje se prema Zakonu o porezu na dohodak ne plaća porez na dohodak,

primitke koji se fizičkim i pravnim osobama isplaćuju po osnovi dividendi i udjela u dobiti.“

Podnositelj prijedloga naglašava da je prednje navedenom odredbom cit. Zakona povrijeđeno načelo pravednosti, jednakosti i razmjernosti na koje se zakonodavac poziva u čl. 1. spornog Zakona.

Također je čl. 51. Ustava RH određeno da je svatko dužan sudjelovati u podmirenju javnih troškova u skladu sa svojim gospodarskim mogućnostima. Iz navedene odredbe čl. 4. Zakona o posebnom porezu na plaće, mirovine i druge primitke razvidno je da se odredbe predmetnog zakona ne primjenjuju na sve kategorije građana koji ostvaruju primitke, pa je tako jasno vidljivo da predmetni porez neće plaćati osobe koje ostvaruju primitke od samostalne djelatnosti, a kojih je po nekim objektivnim procjenama više od sto tisuća.

Ako uzmemo u obzir činjenicu da građani koji ostvaruju prihode od samostalne djelatnosti u većini slučajeva ostvaruju vrlo visoke prihode u odnosu na prosjek u RH, proizlazi da se predmetnim zakonom krši načelo jednakosti i pravednosti odnosno određenje RH kao socijalne države.

Nadalje, odredbom čl. 5. Zakona o posebnom porezu na plaće, mirovine i druge primitke (NN 94/09) određeno je: „Poseban porez na plaće, mirovine i druge primitke plaća se: 
1. po stopi od $2 \%$ na ukupni iznos place, mirovine i drugog primitka iz čl. 4 . st. 2. do 7. ovoga zakona, ako je iznos veći od 3000,00 kn, a manji od 6000,00 kn ukupno u tijeku jednog mjeseca,

2. po stopi od $4 \%$ na ukupni iznos plaće, mirovine i drugog primitka iz čl. 4. st. 2. do 7. ovoga zakona, ako je iznos veći od 6000,00 kn ukupno u tijeku jednog mjeseca.

Navedenom odredbom zakonodavac ponovno krši načelo razmjernosti u podmirenju javnih troškova, odnosno načela jednakosti i pravednosti poreznog sustava RH. Iz te je odredbe jasno uočljivo da poseban porez na plaće, mirovine i druge primitke ne plaća osoba čija je plaća, mirovina ili drugi primitak manji od 3000,00 kn, kao što je i jasno uočljivo da predmetni porez ne plaća niti osoba čija je plaća, mirovina ili drugi primitak u iznosu od 6000,00 kn.

Podnositelj prijedloga ističe da je protivno načelu jednakosti i pravednosti da netko tko prima plaću, mirovinu ili drugi primitak u iznosu od 2999,99 kn ne plaća predmetni porez, a da ona osoba koja prima plaću, mirovinu ili drugi primitak u iznosu od 3000,00 kn i više do 6000,00 kn plaća taj porez. Također, kao što je naglašeno iz predmetne odredbe čl. 5. spornog Zakona, proizlazi da se predmetni porez ne plaća ako se prima točno iznos od $6000,00 \mathrm{kn}$. Nije poznato čime se zakonodavac rukovodio određujući navedene iznose i stope po kojima se plaća, odnosno ne plaća posebni porez, ali je očito da je na ovaj način ostavio mogućnost zloporabe spornog Zakona.

Zbog toga podnositelj prijedloga smatra da je odredba čl. 5. osporenog Zakona u protivnosti s načelom jednakosti i pravednosti, pa je sukladno ovim načelima porezna stopa trebala biti određena $\mathrm{u}$ jedinstvenom postotku, a ne različito s obzirom na visinu primanja.

Podnositelj prijedloga smatra da su spornim Zakonom povrijeđene i odredbe čl. 35. i 55. st. 1. Ustava RH, jer se propisivanjem spomenutih odredbi onemogućava dostojanstven život, s obzirom na to da građani svojom zaradom i mirovinom ne mogu osigurati sebi i obitelji slobodan i dostojanstven život u kojemu im neće biti povrijeđeno dostojanstvo, ugled i čast.

III. Sukladno svemu iznesenome, razvidno je da je Zakon o posebnom porezu na plaće, mirovine i druge primitke (NN94/09) neustavan te da isti predstavlja očito kršenje odredaba čl. 1. st.1., čl. 5., čl. 14., čl. 35., čl. 51. i čl. 55. st. 1. Ustava Republike Hrvatske. Dakle, očigledno je da je spornim Zakonom povrijeđeno načelo ustavnosti iz čl. 5. Ustava čijim se sadržajem ograničavaju ustavna prava građana iz čl. 14., 35., 51. i 55. st.1. u svezi s čl. 1. st. 1. Ustava Republike Hrvatske.

IV. Temeljem svega iznesenoga, predlaže se da Ustavni sud pokrene postupak radi ocjene suglasnosti Zakona o posebnom porezu na plaće, mirovine i druge primitke (NN94/09) i njegovih odredbi čl. 1. st. 1., 4. i 5. te da nakon provedenog 
ustavnosudskog postupka utvrdi njihovu nesuglasnost s Ustavom te ih ukine i ukloni njihovu primjenu iz pravnog poretka RH, kako bi se na taj način spriječilo daljnje kršenje Ustavom određenih i zajamčenih ljudskih prava i sloboda.

Vlastoručni potpis podnositelja i pečat za pravne osobe

\section{LAMENTIRANJE PO POJEDINIM STAJALIŠTIMA USTAVNOG SUDA RH}

Ustavni je sud razmatrano rješenje primarno utemeljio na odredbama čl. 35 ., 37., 38., 39., 40., 43. i 44. Zakona o Ustavnom sudu, komparirajući pri tome svoju dosadašnju ustavnosudsku praksu i praksu ESLJP-a na koje se pozvao u obrazloženju temeljem čega je podnositeljev zahtjev za ocjenu suglasnosti Zakona o financijskom poslovanju i predstečajnoj nagodbi s Ustavom RH preimenovao u prijedlog za pokretanje postupka za ocjenu suglasnosti navedenog Zakona s Ustavom. Pri tome je naglasio da je doneseno rješenje precedentnog karaktera, što znači da važi i za buduće slučajeve.

\subsection{O institucionalnom pristupu i kvalificiranim pokretačima ustavnosudskog postupka}

Zahtjev kojim se pokreće postupak pred Ustavnim sudom mogu podnijeti samo oni koji su određeni u čl. 35. Ustvnog zakona, a među njima i Vrhovni sud RH i svaki drugi sud, ako pitanje ustavnosti i zakonitosti nastane u postupku vođenim pred tim sudom. To su prema stajalištu Ustavnog suda tzv. kvalificirani pokretači postupka ex lege. Međutim, prijedlog za pokretanje postupka za ocjenu suglasnosti zakona s Ustavom može pak podnijeti svaka fizička i pravna osoba, iako su sadržaj zahtjeva i prijedloga isti, pa je stavljen naglasak na razlici u osobama podnositelja.

Što se tiče zastajanja s postupkom, izražen je stav da prilikom odluke o zastajanju s postupkom mora već biti pripremljen zahtjev Ustavnom sudu i s istim moraju biti upoznati sudionici u postupku.

Prema odredbama čl. 44. st. 1. Ustavnog zakona, postupak za ocjenu suglasnosti zakona s Ustavom i drugih propisa s Ustavom i zakonom smatra se pokrenutim danom primitka zahtjeva u Ustavnom sudu, odnosno na dan predaje zahtjeva preporučenom poštom.

O pokretanju postupka za ocjenu suglasnosti zakona s Ustavom i drugih propisa s Ustavom i zakonom u povodu prijedloga, smatra se pokrenutim na dan donošenja rješenja o pokretanju postupka (čl. 44. st. 2. cit. Zakona), pa se tu ne radi samo o različitim terminima od kada se postupak smatra pokrenutim, nego i o prednosti koja se daje postupanju sa zahtjevom za razliku od prijedloga. 
Ustavni je sud naglasio kako je u svojoj dosadašnjoj praksi zauzimao stajalište da se Ustavni zakon opredijeli za tzv. ,institucionalni pristup“ Ustavnom sudu i to samo „kvalificiranim pokretačima“ ustavnosudskog postupka za ocjenu ustavnosti pravnih normi, kao što su tijela državne uprave i javne vlasti (uz iznimku koja se tiče zakonodavne grane vlasti). Tako povezujući odredbe čl. 35. alin. 5 s čl. 39. Ustavnog zakona, posebno one o potpisu i pečatu podnositelja zahtjeva, izvodi zaključak da su se kao kvalificirani pokretači postupka za ocjenu ustavnosti pravnih normi pred Ustavnim sudom mogla pojaviti samo tijela koja zastupaju njihovi čelnici, a ne njihove ustrojstvene jedinice ili fizičke osobe u svojstvu nositelja odgovarajućih funkcija unutar tih tijela.

Što se tiče sudbene vlasti, Ustavni sud ne pravi razliku između sudova i ostalih kvalificiranih pokretača ustavnosudskog postupka za ocjene ustavnosti pravnih normi, pa nije isključio mogućnost da zahtjev za ocjenu suglasnosti zakona s Ustavom potpiše konkretni sudac ili predsjednik konkretnog sudskog vijeća, ali je smatrao da aktivitet suda, kada se on obraća Ustavnom sudu s navedenim zahtjevom jest aktivitet tijela državne vlasti (institucionalni kriterij) koje pred Ustavnim sudom mora predstavljati predsjednik suda kao najviše tijelo sudske uprave u sudu, a sam zahtjev mora sadržavati njegov potpis i pečat suda kojim se služi predsjednik suda. Za takav stav nalazi uporište i u ranijim odredbama čl. 13. i 14. Ustavnog zakona iz 1991. godine. Zbog toga smatra da ni Ustavni zakon koji je u primjeni nije unio bitne novine u taj institut, osim što je krug kvalificiranih pokretača ustavnosudskog postupka za ocjenu ustavnosti pravnih normi proširio, pored Vrhovnog suda RH, i na sve ostale sudove u Republici Hrvatskoj. I dalje je motrišta da Ustavni zakon nije izjednačio suca s tijelima državne i javne vlasti kao kvalificiranim pokretačem ustavnosudskog postupka. Smatra da je riječ o ekskludiranju suca kao osobnog nositelja sudačke funkcije u sudu u smislu čl. 118. st. 1. Ustava samo iz kategorije kvalificiranih pokretača postupka za ocjenu ustavnosti pravnih normi pred ustavnim sudom. Time da nikada nije dovedena u pitanje ovlast suca da osporava ustavnost zakona i drugih propisa pred Ustavnim sudom na temelju čl. 38. st. 1. Ustavnog zakona, niti njegova ovlast da u konkretnom sudskom postupku odlučuje o svim pitanjima koja su inherentna funkciji suđenja.

Iz ovakvog shvaćanja Ustavnog suda može se razabrati da sudac koji vodi postupak predstečajne nagodbe jest personifikacija suda i ovlašten je donositi sve propisane odluke u postupku predstečajne nagodbe, osim u slučaju kada se sa zahtjevom za ocjenu suglasnosti zakona s Ustavom obraća Ustavnom sudu. Za taj svoj stav nalazi uporište u Ustavnom zakonu iz 1991. god. Međutim, stricto sensu čak ni iz odredbi čl. 13. i 14. tog ranijeg Ustavnog zakona to izravno ne proizlazi, da bi se isti oslanjao na institucionalni kriterij, jer je prema tim odredbama bilo propisano da zahtjev kojim se pokreće postupak pred Ustavnim sudom može podnijeti Vrhovni sud RH, ako pitanje ustavnosti i zakonitosti nastane u postupku pred sudovima. Međutim, kada je već riječ o tom kriteriju, ni „petina zastupnika“ ili radno tijelo Hrvatskog sabora ne bi potpadali pod taj kriterij, a mogu se izravno obraćati sa svojim zahtjevima za ocjenu ustavnosti propisa Ustavnom sudu. 
Odredbe čl. 37. st .1. u svezi s čl. 35. alineja 5. Ustavnog zakona jasne su i ne trebaju dodatnih interpretacija kada propisuju da zahtjev kojim se pokreće postupak pred Ustavnim sudom mogu, pored ostalih, podnijeti i Vrhovni sud RH ili bilo koji drugi sud, ako pitanje ustavnosti i zakonitosti nastane u postupku vođenim pred tim sudom i ako sud u postupku utvrdi da zakon koji bi trebao primijeniti, odnosno pojedina njegova odredba, nisu suglasni s Ustavom, da ce zastati s postupkom i podnijeti Ustavnom sudu zahtjev za ocjenu suglasnosti zakona, odnosno pojedine njegove odredbe s Ustavom. Osnovano se možemo upitati tko je sud u postupku, što obuhvaća sudačka dužnost, tko utvrđuje nesuglasnost propisa s Ustavom i zastaje s postupkom te podnosi zahtjev Ustavnom sudu.

Prema odredbama čl. 120. Ustava, sudačka dužnost povjerava se osobno sucima, a u suđenju sudjeljuju suci i suci porotnici u skladu sa zakonom. Prema tim odredbama očito je da je sudac personifikacija suda u obavljanju sudačke dužnosti. Zato se u sudskim odlukama ne spominje sudac koji poduzima određene radnje u postupku, nego sud. Kako će to sudac suditi i donositi odluke na temelju Ustava i zakona, ako ne može izravno provjeravati neustavnost zakona ili drugog propisa koji treba primijeniti? Tko bi tu i takvu provjeru u postupku što ga vodi trebao vršiti umjesto njega? Stoga nije slučajno Ustavni zakon čl. 35. koji je u primjeni pored Vrhovnog suda RH ovlastio i sve druge sudove na pokretanje zahtjeva, a čl. 37. istog Zakona im to propisao kao dužnost. Međutim, ako je Ustavni sud ipak smatrao, na osnovi dosadašnje ustavnosudske prakse na koju se pozvao, da u postupku ocjene ustavnosti pravne norme pred Ustavnim sudom važeći Ustavni zakon nije izjednačio suca s tijelima državne i javne vlasti kao kvalificiranog pokretača postupka, trebao je takav podnesak $s$ istaknutim zahtjevom vratiti podnositelju na ispravak s potrebnim uputama te da ga ujedno potpiše i predsjednik prvostupanjskog suda i opremi pečatom suda kojim se on služi te vrati natrag u ostavljenom roku, što bi bilo u skladu s odredbama čl. 19. i 34. Ustavnog zakona.

\subsection{Pretvorba zahtjeva u prijedlog za ispitvanje neustavnosti ZFPPN-a i zastoj postupka}

No, Ustavni sud nije tako postupio, nego se opet pozvao na postojeću ustavnosudsku praksu prema kojoj u slučajevima kad nisu bile ispunjene pretpostavke iz čl. 37. st. 1. Ustavnog zakona, takav se zahtjev ne odbacuje nego će ga se smatrati prijedlogom za pokretanje postupka u smislu odredbe čl. 38. st. 1 . Ustavnog zakona. Ta dugogodišnja, ustaljena i jednoobrazna ustavnosudska praksa ima se smatrati pravom „law" u kojem smislu relevantnost sudske prakse tumači i ESLJP pozivom na nabrojene slučajeve u svojem obrazloženju. Sam Ustavni sud naglašava da su ovakva utvrđenja važna, jer razlikovanje zahtjeva i prijedloga može imati konkretne pravne posljedice na prava stranaka u sudskim postupcima. Ta je konstatacija Ustavnog suda točna, zbog čega se i vodi polemika u svezi s donesenim njegovim rješenjem, koje smatra presedantskim karakterom. 
Samo kada je riječ o zahtjevu iz čl. 37. st. 1. u svezi s čl. 35. alineja 5. i čl. 39. Ustavnog zakona, nadležni sud ima pravnu osnovu zastajanja s konkretnim postupkom, ali takvu osnovu nema kada je riječ o prijedlogu iz čl. 38. st. 1. Ustavnog zakona. U svezi s tim Ustavni sud prihvaća ustaljeno stajalište ESLJP-a, izraženo u predmetu Micallef c/a Malte, s tim da zbog interesa pravne sigurnosti, predvidljivosti i jednakosti pred zakonom Sud ne bi smio odstupiti bez dobrog razloga od svoje prakse koja je stvorena u prijašnjim slučajevima, ali i stajališta da bi propust Suda da održava dinamičan i evolutivan pristup mogao dovesti do kočenja reforme ili napretka. Kako u razmatranom predmetu u ovom ustavnosudskom postupku ne postoji rizik da bi dosadašnja praksa Ustavnog suda bila kočnicom reformi ili napretka u ovom predmetu prednost se mora dati interesima pravne izvjesnosti, predvidljivosti i jednakosti pred zakonom i u tom smislu poštovati praksu Ustavnog suda. Da li se u ovom predmetu moglo ipak odstupiti s dobrim i opravdanim razlogom od te prakse?

Što ako doista iz neustavnosti pojedinih odredbi ZFPPN-a, na koje je ukazano u zahtjevu, to proizlazi? Pored toga, Ustavni sud uvažava činjenicu da je Ustavni zakon prepustio ustavnosudskoj praksi pobližu razradu čl. 37. st. 1. Ustavnog zakona u svjetlu zahtjeva koje postavlja vladavina prava, najviša vrednota ustavnog poretka Republike Hrvatske, kao i činjenicu da su sudovi od 1991. god. do danas rijetko podnosili zahtjeve Ustavnom sudu za ocjenu ustavnosti zakona na temelju čl. 37. st. 1. Ustavnog zakona, odnosno čl. 14. st. 1. Ustavnog zakona o Ustavnom sudu RH (NN 13/91), a kada su ih i podnosili, nisu Ustavnom sudu dostavljali rješenje o zastajanju s postupkom, pa u dosadašnjoj praksi nije ni zabilježeno osporavanje takvih rješenja pred Ustavnim sudom. Kako se onda takvi zahtjevi i nepostojanje izgrađene ustavnosudske prakse najednom pretvaraju u ustaljenu praksu Ustavnog suda, čija bi izmjena dovela do ugrožavanja interesa pravne sigurnosti, predvidljivosti i jednakosti pred zakonom? Izraženim stajalištem Ustavnog suda stječe se upravo protivan dojam.

\subsection{O preliminarnom postupku i prethodnim prigovorima}

Ustavni sud posebno objašnjava svoje stajalište u svezi s prethodnim prigovorima (preliminary objection), pozivajući se na praksu koju je izgradio ESLJP u njihovoj primjeni, smatrajući da su ti prigovori, kada je doneseno rješenje o zastajanju s postupkom u slučaju primjene čl. 37. st. 1. Ustavnog zakona, dopušteni i u domaćem pravnom poretku. Ovlaštenje za njihovo podnošenje imaju stranke u sudskom postupku s kojim se zastalo sve dok zastajanje s postupkom traje. Te prethodne prigovore Ustavni sud razmatra u preliminarnom postupku vezanom uz podnesak suda kojim se podnosi zahtjev za ocjenu ustavnosti zakona koji se trebao primijeniti u sudskom postupku s kojim se zastalo, zbog čega je broj ovog ustavnosudskog spisa dobio dodatak PP (preliminarni postupak). Primjenjujući navedena pravila na konkretan slučaj, Ustavni je sud utvrdio da se podnesak Dalekovoda d.d. Zagreb, nazvan „ustavna tužba“, u određenim dijelovima može smatrati prethodnim 
prigovorima na podnesak suda o podnošenju zahtjeva za ustavnosudsku zaštitu u smislu čl. 37. st. 1. Ustavnog zakona. Ostali prigovri Dalekovoda d.d. Zagreb, sadržani u podnesku nazvanom „ustavna tužba“, nemaju svojstvo prethodnih prigovora, pa su isti odbačeni.

Ako je Dalekovod d.d. Zagreb, koji zastupaju kvalificirani punomoćnici, podnio samostalnu ustavnu tužbu, koja je trebala dobiti svoj poseban poslovni broj, kojim je to postupkom Ustavni sud istu pretvorio u podnesak kojim se djelomično ističu prethodni prigovori u predmetu Ustavnog suda U-I-4175/2013, kad mogućnost takvih prigovora ne propisuje odredba čl. 37. st. 1. niti ostale odredbe Ustavnog zakona? Ta ustavna tužba Dalekovoda d.d. Zagreb niti se ne poziva na ustavnosudski spis U-I-4175/2013, da bi se eventualno po svojem sadržaju mogla smatrati prethodnim prigovorima od kojih su jedni prihvaćeni, a drugi odbačeni, umjesto da ustavna tužba bude odbačena u cijelosti.

\subsection{O ukidanju rješenja o zastajanju s postupkom i njegovim nastavljanjem}

Ustavni sud ukida rješenje Trgovačkog suda u Zagrebu broj: Stpn-7/2013 od 22. srpnja o zastajanju s postupkom u predmetu Stpn-7/13 i nalaže njegovo bezodložno nastavlajnje.

Prema odredbi čl. 45. Ustavnog zakona, Ustavni sud do donošenja konačne odluke može privremeno obustaviti izvršenje pojedinačnih akata ili radnji koje se poduzimaju na osnovi zakona ili drugog propisa čija se suglasnost s Ustavom odnosno zakonom ocjenjuje, ako bi njihovim izvršenjem mogle nastupiti teške i nepopravljive štetne posljedice. Ako je Ustavni sud već ukinuo to rješenje, suvišno je naložio njegovo bezodložno nastavljanje, jer je njegovim ukidanjem prestalo njegovo djelovanje koje je bilo konstitutivnog karaktera.

\subsection{O ostalim nedostacima koje sadržava podnesak uređujućeg suca pojedinca}

Ustavni je sud, pored navedenoga, istakao da podnesak suca pojedinca kojim je podnio zahtjev za ocjenu neustavnosti odredaba ZFPPN-a pati i od drugih nedostataka s obzirom na spomenute odredbe čl. 35. alineja 5 u svezi s odredbom čl. 37. st. 1. Ustavnog zakona. Tako pitanje ustavnosti spornog zakona mora nastati u postupku vođenim pred tim sudom, što znači da se u zahtjevu mora naznačiti u svezi s kojim se postupkom koji se vodi pred sudom pojavilo pitanje ustavnosti određenog zakona, odnosno pojedine njegove odredbe. Ovo zato što je zahtjevom dopušteno osporavanje ustavnosti samo onih odredaba zakona koje treba primijeniti u tom sudskom postupku, a ne bilo koje odredbe, bilo kojeg zakona. Iznesene tvrdnje o neustavnosti zakonskih odredaba potrebno je obrazložiti na konkretnom predmetu na koje bi se one trebale primijeniti, jer kada je u pitanju primjena čl. 37. st. 1 . 
Ustavnog zakona riječ o specifičnoj konkretnoj kontroli ustavnosti pravnih normi. Podnesak što ga je uređujući sudac pojedinac podnio Ustavnom sudu ne poštuje navedena pravila, jer je u tom podnesku općenito osporio suglasnost pojedinih odredbi ZFPPN-a s Ustavom, ali ih ni na koji način nije povezao s činjenicama i okolnostima konkretnog predmeta Trgovačkog suda u Zagrebu koji se vodi pod. brojem Stpn-7/13 u kojem je zastao s postupkom, niti je obrazložio razloge zbog kojih smatra da u tom predmetu odredbe ZFPPN-a proizvode učinke koji su protivni Ustavu RH. Stoga se i po toj osnovi podnesak uređujućeg suca pojedinca ne može smatrati zahtjevom, nego se ima smatrati prijedlogom za pokretanje postupka za ocjenu suglasnosti ZFPPN-a s Ustavom u smislu čl. 38. st. 1. Ustavnog zakona.

Međutim, Trgovački sud u Zagrebu, po sucu pojedincu M. K., u podnesku od dana 29. srpnja 2013. godine koji je dostavio Ustavnom sudu, naveo je da je Trgovački sud u Zagrebu po navedenom sucu donio odluku Stpn-7/13 od 22. srpnja 2013. god. kojom je zastao s postupanjem u ovom predmetu predstečajne nagodbe te sukladno odredbi čl. 37. st. 1. i čl. 35. Ustavnog zakona podnosi zahtjev za ocjenu suglasnosti pojedinih odredbi ZFPPN-a s Ustavom. Smatramo da je time sudac postupio kako mu Ustavni zakon nalaže, jer je sud dužan podnijeti zahtjev, a ne prijedlog.

Ustavni sud je toč. II. razamatranog rješenja ukinuo rješenja Trgovačkog suda Zagreb broj: Stpn-7/13 od 22. srpnja o zastajnju s postupkom u predmetu Stpn7/13 te naložio njegovo bezodložno nastavljanje. Dakle, očito je da se radi o istom predstečajnom predmetu. Što se tiče konkretnog postupka, po podnesku uređujućeg suca pojedinca kojim je uputio sporni zahtjev od 29. srpnja 2013. god. Ustavnom sudu, a nakon što je detaljno naveo i opisao sporne odredbe ZFPPN-a opisujući dva slučaja s učinkom spornih odredbi u praksi od kojih je jedan upravo ovaj pod br. Stpn-7/13, moglo se ustanoviti zbog kojih razloga smatra da su u tom predmetu pojedine navedene odredbe ZFPPN-a neustavne. Pored toga, podneseni je zahtjev popraćen odgovarajućom dokumentacijom radi mogućnosti provjere spornih okolnosti i činjenica, ali valja uložiti dodatni napor da se sve to prouči s obzirom na novosti postupka predstečajne nagodbe. Ako bi se ipak i nakon toga došlo do spoznaje da zahtjev nije postavljen suglasno odredbama čl. 39. Ustavnog zakona, tada je Ustavni sud, suglasno odredbama čl. 19. i 34. Ustavnog zakona, mogao istog vratiti natrag s uputom na ispravak u određenom roku, a ne utvrditi da je umjesto zahtjeva podnesen prijedlog za pokretanje postupka za ocjenu suglasnosti s Ustavom Zakona o financijskom poslovanju i predstečajnoj nagodbi, bez obzira na to što je podredno uređujući sudac pojedinac tako u svojem citiranom podnesku naveo. 


\section{ZAKLJUČNA RAZMATRANJA}

U Republici Hrvatskoj zakoni moraju biti u suglasnosti s Ustavom, a ostali propisi s Ustavom i zakonom (čl. 5. st. 1. Ustava RH). Svatko se dužan držati Ustava i zakona i poštovati pravni poredak Republike Hrvatske (čl. 5. st. 2. Ustava RH). Sudovi su u obavljanju svoje funkcije samostalni i nezavisni te sude na temelju Ustava i zakona. Međunarodni ugovori koji su sklopljeni u skladu s Ustavom i objavljeni, a koji su na snazi, čine dio unutarnjeg pravnog poretka Republike Hrvatske, a po pravnoj su snazi iznad zakona (čl. 141. Ustava RH).

Sud nije ovlašten sam zauzeti stav o neustavnosti zakona i izravno primijeniti odredbe Ustava, nego je dužan pričekati odluku Ustavnog suda po tom pitanju, nakon što pokrene postupak pred Ustavnim sudom za ocjenu suglasnosti zakona s Ustavom ili suglasnosti drugih propisa s Ustavom i zakonom. Postupak se može pokrenuti na tri načina i to: a) zahtjevom ovlaštenog državnog tijela, odnosno predstavničkog tijela jedinice lokalne ili područne (regionalne) samouprave, Vrhovnog suda Republike Hrvatske ili bilo kojeg drugog suda, ako pitanje ustavnosti i zakonitosti nastane u postupku vođenom pred tim sudom te pučki pravobranitelj u postupcima iz čl. 92. Ustava (čl. 37. st. 1. Ustavnog zakona), b) prijedlogom bilo koje fizičke ili pravne osobe za pokretanje postupka za ocjenu suglasnosti zakona s Ustavom i ocjenu suglasnosti drugih propisa s Ustavom i zakonom na temelju posebne odluke Ustavnog suda o tome (čl. 38. st. 1. Ustavnog zakona), te c) samoinicijativno (ex offo) od strane Ustavnog suda (čl. 38. st. 2. Ustavnog zakona).

Sudovi su ovlašteni i dužni zahtjevom pokrenuti pred Ustavnim sudom postupak za ocjenu suglasnosti zakona s Ustavom ili postupak za ocjenu suglasnosti drugih propisa s Ustavom i zakonom. Za pokretanje tih postupaka primjenjuju se različite pretpostavke. Dakle, sud je nedvojbeno dužan i ovlašten podnijeti Ustavnom sudu zahtjev za ocjenu suglasnosti zakona s Ustavom, odnosno pojedine njegove odredbe s Ustavom, kada u tijeku postupka utvrdi da zakon koji treba primijeniti, odnosno pojedina njegova odredba nisu suglasni s Ustavom. Sud će u tom slučaju zastati s postupkom (čl. 37. st. 1. Ustavnog zakona). Ako sud u tijeku postupka utvrdi da drugi propis koji bi trebalo primijeniti, odnosno pojedina njegova odredba nisu suglasni s Ustavom i zakonom, primijenit će zakon (exceptio illegalitatis), a Ustavnom će sudu podnijeti zahtjev za ocjenu suglasnosti spornog propisa, odnosno pojedine njegove odredbe s Ustavom i zakonom (čl. 37. st. 2. Ustavnog zakona). O podnesenim zahtjevima Ustavni je sud dužan izvijestiti Vrhovni sud Republike Hrvatske (čl. 37. st. 3. Ustavnog zakona).

Zahtjev suda za ocjenu suglasnosti zakona s Ustavom i suglasnosti drugih propisa s Ustavom i zakonom mora sadržavati: a) oznaku odredaba čija se ustavnost odnosno zakonitost osporava, b) oznaku odredaba Ustava ili zakona za koje se u zahtjevu tvrdi da su povrijeđene, c) razloge zbog kojih se tvrdi da osporeni propis nije suglasan s Ustavom, odnosno zakonom, d) potpis i pečat podnositelja zahtjeva (čl. 39. st. 1. Ustavnog zakona). U zahtjevu podnositelj može navesti i druge činjenice od značenja za ocjenu stvari i svoje mišljenje o tome treba li osporeni propis ukinuti 
ili poništiti (čl. 39. st. 2. Ustavnog zakona). Uz zahtjev za pokretanje postupka za ocjenu ustavnosti i zakonitosti drugog propisa mora se priložiti i osporavani akt (čl. 39. st. 3. Ustavnog zakona).

Postupak za ocjenu suglasnosti zakona s Ustavom i drugih propisa s Ustavom i zakonom smatra se pokrenutim na dan primitka zahtjeva u Ustavnom sudu, odnosno na dan predaje zahtjeva pošti preporučenom pošiljkom (čl. 44. st. Ustavnog zakona).

Prijedlog za pokretanje postupka za ocjenu suglasnosti zakona s Ustavom i suglasnosti drugih propisa s Ustavom i zakonom u pravilu sadrži sve ono što sadrži i zahtjev (čl. 40. st. 1. Ustavnog zakona), a Ustavni sud će započeti postupak najkasnije u roku od godine dana od podnošenja prijedloga (čl. 40. st. 2. Ustavnog zakona).

Prema čl. 17. st. 1. Ustavnog zakona, postupak pred Ustavnim sudom pokreće se pisanim zahtjevom, prijedlogom i ustavnom tužbom (u daljnjem tekstu podnesci). Podnesci upućeni Ustavnom sudu moraju biti razumljivi i moraju sadržavati sve što je potrebno da bi se po njima moglo postupiti (čl. 19. st. 1. Ustavnog zakona). Ako je podnesak nerazumljiv ili ne sadrži sve što je potrebno da bi se po njemu moglo postupiti, Ustavni sud će ga vratiti podnositelju radi ispravka, odnosno dopune uz određivanje roka za ponovno podnošenje. Prema odredbi čl. 34. Ustavnog zakona, ako Ustavnim zakonom nije drukčije propisano, Ustavni sud u postupku podredno smisleno primjenjuje odredbe odgovarajućih postupkovnih zakona Republike Hrvatske, pa tako i odrebe čl. 109. Zakona o parničnom postupku prema kojima se prilikom vraćanja podneska podnositelju treba istog i upozoriti na nedostatke njegova podneska i zahtjeva, koji nedostaci, ako postoje, otklonjivi su u određenom roku čl. 19. st. 2. Ustavnog zakona. Ako podnesak s uređenim zahtjevom u određenom roku ne bi bio vraćen Ustavnom sudu, smatralo bi se da je isti povučen, a ako bi bio vraćen bez ispravka, odnosno dopune, bio bi odbačen (čl. 19. st. 4. Ustavnog zakona).

Umjesto da Ustavni sud primijeni navedene jasne odredbe Ustavnog zakona, koji je izjednačio sudove s Vrhovnim sudom Republike Hrvatske po svojem ovlaštenju i dužnosti na podnošenje zahtjeva za ocjenu suglasnosti zakona, odnosno pojedine njegove odredbe, on se po našem mišljenju upustio u njihovu dvojbenu interpretaciju i konstrukciju radi opravdanja zauzetih stajališta na temelju kojih je izveo preinaku zahtjeva podnositelja u prijedlog podnositelja. Slijedeći takva zauzeta stajališta Ustavnog suda može se očekivati da ni prijedlog za pokretanje postupka za ocjenu suglasnosti ZFPPN-a s Ustavom neće biti prihvaćen, jer on pati od istih nedostataka kao i zahtjev, bez obzira na to što ga je podnio uređujući sudac pojedinac. Ustavni sud bi na taj način riješio spis U-I-4175/2013, ali ne bi riješio problem koji se ogleda u očitoj neustavnosti pojedinih odredbi spornog Zakona kojim je regulirana predstečajna nagodba, a koje se prvenstveno odnose na: pokretanje postupka dužnika, glasovanje (malih i velikih) vjerovnika i njihovu suglasnost s prijedlogom nagodbe, na prijavljivanje, ispitivanje i utvrđivanje njihovih tražbina, vođenje i kontrolu postupaka pred Financijskom agencijom, detaljnih dužnosti revizora i dr. na što se u praksi već duže vrijeme upozorava. Zbog toga su najavljene i njegove 
skorašnje izmjene o kojima se već dulje vodi javna polemika kako bi se uklonile uočene mogućnosti dosadašnjih zloporaba na koje se ukazivalo u praksi. Kako je institut predstečajne nagodbe u ovim kriznim vremenima od velikog gospodarskog i socijalnog značaja, moglo se opravdano očekivati da će Ustavni sud, koji sigurno prati što se u provođenju ovako važnog propisa u praksi događa, samoinicijativno pokrenuti postupak za ocjenu ustavnosti spornog Zakona o financijskom poslovanju i predstečajnoj nagodbi, odnosno pojedinih njegovih odredbi, ali se to, na žalost, do danas nije dogodilo.

No, kako u postupku za ocjenu ustavnosti odnosno zakonitosti in abstracto ne važi princip „,ne bis in idem“, Ustavni sud može ocijeniti da je prijedlog za pokretanje postupka za ocjenu suglasnosti ZFPPN-a s Ustavom osnovan, odnosno tražiti uklanjanje nedostataka na koje je u razmatranom rješenju upozorio i nastaviti postupak, bez obzira na precedentnost tog rješenja. 


\section{ANALYSIS OF THE JUDGEMENT OF THE CONSTITUTIONAL COURT OF THE REPUBLIC OF CROATIA NO: U-I-4175/2013-PP FROM 27. VIII. 2013.}

The pre-bankruptcy settlement regulated by the Financial Business and Pre-bankruptcy Settlement Act (NN 108/12,144/12,81/13, 112/13) reminds one of the recent out of bankruptcy coercive court settlement. The intention of this Act was to prescribe legal norms which would enable speedy and efficient restoration of insolvent, illiquid and over indebted economic subjects. In this Act there are no indications that such a settlement would be of a coercive nature, but during its application in practice, it was evident that certain provisions lead to such a possibility. Therefore, submitting a request for an assessment of the constitutionality of its provisions to the Constitutional Court of the Republic of Croatia ensued. These provisions placed certain participants of the prebankruptcy settlement in a more favorable position and in that way enabled misuse which was pointed out in the submitted request. The Constitutional Court of the Republic of Croatia in relation to the submitted request handed down judgement number: U-I-4175/2013-PP of August 27 2013. This, in its preliminary proceeding, considering partially submitted complaints of debtors in bankruptcy settlement, reformulated the submitted request into a suggestion for assessment of approval of the given Act. That is, the Constitutional Court of Croatia certain of the Acts' provisions with the Constitution of the Republic of Croatia, vacated the judgement which provided for delaying the procedure and ordered for the procedure to promptly continue. As the Constitutional Court of Croatia stated that the reached Judgement was of a precedential nature, the author analyzed the position taken by the Constitutional Court of Croatia which was on the basis of reached decisions and realized that given the importance of this problem area a different Judgement could and should be reached and considered that it should not in the future have a precedential nature.

Key words: Constitutional Law, request, suggestion, delaying proceedings, preceding complaints, preliminary proceeding, qualified initiator 